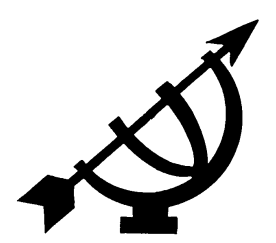

\title{
Mind control: The secret weapon utilised by religious cults to control their followers
}

\author{
S.P. Pretorius \\ Registration Administration \\ UNISA \\ PRETORIA \\ E-mail:pretosp@unisa.ac.za
}

\begin{abstract}
Mind control: The secret weapon utilised by religious cults to control their followers

The aim of this article is to create awareness of the dangers of religious cults. The process utilised by these cults to recruit members and to control their lives is so subtle that members are led to believe that they joined out of their own free will. A brief discussion of what religious cults are as well as how they function is followed by an explanation of mind control and how it is utilised by cults. This article maintains that mind control is the secret weapon with which leaders of cults lure their followers under false pretences to mislead, control and make them dependent on the cult.
\end{abstract}

\section{Opsomming}

Psigiese beheer: die geheime wapen wat deur godsdienstige kultes aangewend word om hulle volgelinge te beheer

Die doel van hierdie artikel is om 'n bewustheid vir die gevare van godsdienstige kultes te kweek. Die proses wat deur hierdie kultes aangewend word om lede te werf en uiteindelik te beheer is so subtiel dat dit die oortuiging by die lede laat dat hulle uit vrye wil betrokke is. 'n Oorsigtelike bespreking van wat godsdienstige kultes is asook hoe hulle funksioneer word gevolg deur 'n uiteensetting van "mind control" en die wyse waarop dit deur die kultes aangewend word. Hierdie artikel handhaaf die beskouing dat "mind control" die geheime wapen is waarmee die leiers van kultes hulle volgelinge onder valse voorwensels lok, mislei, beheer en uiteindelik afhanklik maak van die kulte. 


\section{Introduction}

Religious cults in South Africa, their practices and sophisticated techniques seem to be a topic greatly lacking the attention it deserves. Many people when leaving these cults are faced with serious psychological, emotional, physiological and social consequences. Cult watching groups exist in the United States of America with the aim of revealing these consequences and alerting the public and governments to the perceived dangers of cults. In South Africa similar groups exist, e.g. Cult Information and Evangelisation Centre (CIEC) and Rights of Individuals Grant Honour To (RIGHT). Unfortunately these organisations currently do not receive the recognition and support they need from the government and the public. Religious cults are no longer only a phenomenon elsewhere in the world. A number of established religious cults are also functioning under the South African sky, protected by the constitution of the country. According to the Constitution of the Republic of South Africa, Chapter 2, (31)(1)a

Persons belonging to a cultural, religious or linguistic community may not be denied the right, with other members of that community

(a) to enjoy their culture, practise their religion and use their language, and

(b) to form, join and maintain cultural, religious and linguistic associations and other organs of civil society

Most of the South African cults are geographically isolated from the outside world and as a result function as communes on farms. More important is the fact that their members are also emotionally isolated from their known world of reference through subtle techniques, dependence on, and total commitment to the aims and prescriptions of the cult.

Members of these cults show a change in personality and behaviour. Behavioural change in this context mostly results in an antagonism towards family, friends and institutions in disagreement with the doctrines and practices of the cult. Members are known to sell their homes and possessions and pledge the income to the cult as a sign of total commitment to the aims of the cult - the "work of God". More radically, cult members break ties with their family and friends to be left without any support system outside the cult. The question can be asked: How is it possible for people to change so dramatically? And how informed are the public in general about these groups and their practices, so that they will be empowered to take drastic preventative steps? 


\section{Problem statement}

Do members really join a cult out of their own free will? And if so, why is it so difficult to leave the cult after a few years or even months? Why do people who leave these cults encounter psychological, social and physiological problems?

\section{Religious cults}

In order to explore mind control in a religious cult setting, we need to consider a description of what a cult is as well as how cults function.

\subsection{Definition of religious cults}

To define cults is not an easy task, because they are complex religious phenomena. In the hands of some commentators, cults can range from doomsday cults such as Heaven's Gate or the Branch Davidians to those that scarcely seem to be religious at all and merely offer strategies of psychotherapy, positive thinking, or some other means of developing human potential (Hunt, 2003:17).

When investigating religious cults, however, a number of useful definitions emerge: A cult is a relatively small, often transitory religious group that commonly follows a radical leader (Mather \& Nichols, 1993:86) who is believed to have a special talent, gift, knowledge or calling (Singer \& Lalich, 1995:7). A cult espouses radically new religious beliefs and practices that are frequently seen as threatening the basic values and cultural norms of society at large (Mather \& Nichols, 1993:86; Hexham, 1993:59). Bowker $(1997: 247)$ adds to the definition that cults also systematically employ sophisticated techniques designed to effect ego-destruction, thought reform and dependence on the group. Another feature of cults is that they aim to extend their mission independently of previous relationships with family, friends, religion, school or career, employing beliefs, practices and rituals which reinforce cult values and norms (MacHovec, 1989:10).

We can therefore propose the following working definition: a religious cult is a group of people zealously following a leader with a special gift. The cult exhibits radical new religious beliefs and practices in opposition to traditional Christian beliefs. The leader and his or her followers believe that they are the final arbiters of what is or is not the truth. The cult isolates itself from the outside world, exhibiting inward innovative behaviour that both differentiates and makes for conformity among group members establishing a group identity. Sophisticated techniques are utilised in order to bring about 
thought reform (mind control), group identity and dependence on the group.

\subsection{Functioning of religious cults}

According to Singer \& Lalich (1995:8-10), psychologists and experts in the field of cults, three main factors are important in assessing the cultic nature and functioning of a group, namely the leader, the structure of the group and thought reform (mind control).

Cult leaders are self-appointed, persuasive persons who claim to have a special mission, gift or knowledge. For example, Lester Bloomberg of the Mission Church claimed to have the special gift of prophecy (Botha, 1993:11). He prophesied that the town of Welkom would disappear into a hole on 18 April 1988; the AWB would carry out a coup d'état in May 1988; and the Voortrekker monument would be struck by lightning on 16 December 1987 and be divided into two parts (Theron, 1993:287). Furthermore they tend to be determined and domineering and are often described as charismatic. Typically they have enough personal charm or other cogency to attract people, control and manage them. Cult leaders centre veneration on themselves. They keep their followers' love, devotion and allegiance focused on themselves.

Cults exhibit an authoritarian structure and the leader is regarded as the supreme authority. Eugen Houy, the leader of the Houy group in Mpumalanga, claims to receive his messages directly from God (Erasmus, 2004:80). Leaders may delegate some power to a few subordinates in order to ensure that their orders and wishes are carried out. In this group the structure is clearly identifiable. The structure is headed by the leader, Eugen Houy; below him are the seven monarchs, on the next level the priests, then the Levites, and then the people (Erasmus, 2004:18). There is no appeal outside the leadership system to greater systems of justice. Cult leaders claim to be offering something novel and instituting the only viable system for change that will solve life's problems or the world's ills. Almost all cults make the claim that their members are "special", "chosen" or "selected" while non-members are considered lesser beings. Cults tend to have a double set of ethics. Members are urged to confess all to the leader, but at the same time members are encouraged to deceive and manipulate non-members. These actions are explained by "the end justifies the means", or the deception is referred to as "heavenly deception". 
Cults tend to be totalistic, or all encompassing, in controlling their members' behaviour and also ideologically totalistic, exhibiting zealotry and extremism in their world-view. Eventually cults expect members to devote increasing time, money, possessions and resources to the professed goals of the group so that they can obtain salvation. Cults dictate to members what to wear, eat and drink, and when and where they may sleep and work. Miller (2003), a former member of another group in the Limpopo province known as Alon Christian Community, reports that the women who live on the farm with their husbands are told exactly what is expected of them. They must perform specific tasks, which include duties in the kitchen, looking after children and cleaning all the houses on the farm. The women are discouraged from wearing long hair and make-up. They are told that it portrays vanity and will hinder their spiritual growth and total commitment. (The leader's wife, however, is permitted to wear long hair and make-up.) She also told how she had to sleep outside the house she and her husband occupied when she was disobedient to him (she and her husband had been matched up by the leader). She wanted to escape, but was too afraid to do so. Cult members are taught that it is all or nothing. Cults expect their members to undergo a major disruption or change in lifestyle. Great pressure is placed on new members to leave their families, friends and jobs, sell their belongings and pledge their income to the group in order to become immersed in the group's major purpose. This isolation tactic is one of the cults' most powerful and common mechanisms to control their members and enforce dependency.

The sophisticated techniques used to bring about thought reform and behavioural change that ultimately result in isolation and dependence, are of particular interest to this article. These techniques are generally referred to as mind control.

\section{Mind control}

There are different forms of mind control. Mind control in this context refers to the techniques utilised by leaders of religious cults to ensure control over their followers.

\subsection{What is mind control?}

Some definitions of mind control include: A system of influences that disrupts an individual's identity and replaces it with a new identity (Hassan, 1988:7); A step-by-step process designed to break a person's independence and individuality and to substitute it with the 
characteristics of a pawn (McManus \& Cooper, 1984:27). Mind control is the shaping of a person's attitudes, beliefs, and personality without the person's knowledge or consent (www.FACTnet.org.:1). Mind control is also a concerted effort to change a person's way of looking at the world, which will change his or her behaviour (Singer \& Lalich, 1995:62). A person has been made receptive to new ideas, because his or her critical facilities and ego strength have been eroded by techniques including information control, over-stimulation of the nervous system, forced confessions and ego destruction (Snow \& Machaleck, 1984:178).

\subsection{The aim of mind control}

The aim of mind control is to suppress an individual's own personality (ambitions, opinions, critical thinking and ability to make decisions) and to replace it with an identity acceptable to the religious leader. A person who develops this new identity does not think critically, is indecisive, dependent and lacks ambition, thus ensuring that the leader gains control. In this manner the follower is also made dependent on the guidance of the leader and the group.

\subsection{The danger of mind control}

Mind control takes place in a seemingly friendly environment. This friendly environment is created by what purports to be interest in the well-being of the individual. But, on the contrary it is dangerous in view of the fact that the aim is to gain control over the individual. In this environment the individual is more susceptible to such influence, and the establishment of a new identity is more readily achieved. The victim is unknowingly led and manipulated to make certain choices (Hassan, 1988:56). The behaviour changes that take place are viewed as the result of a person's own free will. The subtlety of mind control is clear from the following quotation:

... cults can do it (mind control) better because it's easier to get people to do your bidding through manipulating their guilt and anxiety and by never directly confronting them and frightening them, but to make their own inner guilt and anxiety change their behaviour (McManus \& Cooper, 1984:27).

Another important aspect of the subtlety of mind control is the fact that the leader can never be identified as the culprit in changing the behaviour of his or her followers. Through mind control individuals are unwittingly forced to do what the leader expects of them under the pretence that they have independently decided to do it. When leaders are confronted, they claim innocence on the basis that the 
individuals acted from their own free will. Outsiders unfamiliar with the subtle process of mind control, do not suspect any wrongdoing inside cults. Mind control programs successfully attack the person's central stability, self-concept and capacity for self-evaluation. Moreover, this attack is carried out under a variety of guises and conditions, and only rarely includes forced confinement or direct physical coercion (Singer \& Lalich, 1995:60).

\subsection{Cognitive dissonance}

In order to understand the process of mind control, it is important to explain the principle underlying the process. Cognitive dissonance occurs when an individual is confronted with two or more contradicting cognitions or ideas. The result is that the individual experiences discomfort (Gouws, Louw, Meyer \& Plug, 1982:154). This does not mean that a difference between two cognitions creates dissonance, but rather that a difference exists between cognitions about the self and specific behaviour that nullifies that self-concept (Venter, 2002:141.). In order to obtain consonance an individual will attempt to change one or both of the cognitions (Gerard, 1992:323). An example used by Festinger (1957) may assist in elucidating the theory: A habitual smoker who learns that smoking is bad for his health will experience dissonance, because the knowledge that smoking is unhealthy is dissonant with the cognition that he continues to smoke. He can reduce the dissonance by changing his behaviour, that is, he can stop smoking, which would be consonant with the cognition that smoking is bad for health. Alternatively, the smoker can reduce dissonance by changing his cognition about the effect of smoking on health, and choose to believe that smoking does not have a harmful effect on health (eliminating the dissonant cognition).

In cults, members are confronted in the first instance with a different view and life style that confronts their idea about the self and their behaviour. The view and lifestyle of the cult is presented as "pure" and novel compared to the bad, evil, unfulfilling world-view of the individual. As a result, cognitive dissonance is created. The individual is now forced to make choices or act in order to relieve the discomfort. Throughout the whole process of mind control, this redefining of the self and the member's world-view takes place in order to establish a new identity - the cult identity, to fit the cult world-view. 


\subsection{The process of mind control}

It is clear from the description above that mind control takes place systematically. Different theories exist to account for the process of mind control in religious cults. We will discuss the mind-control process that consists mainly of four phases: first contact, loosening, change and establishment in the cult life style to gain control over followers.

\subsubsection{First contact}

First contact refers to the first time an individual makes contact with the leader or members of a cult. This contact can occur as a result of a friend or family member's introduction to the group. It can also take place during a recruitment exercise of the group. The first contact will be extended by an invitation to an event of the cult (Singer \& Lalich, 1995:112). In cults recruitment and expansion are viewed as part of their mission. "Love bombing", a powerful tool in recruitment of cult members, refers to a feigned show of affection and caring for the sole purpose of influencing behaviour and indoctrinating new members (MacHovec, 1989:82). Love bombing is a coordinated effort, usually under the direction of the leadership, that involves long-term members flooding recruits with flattery, verbal seduction, affectionate but usually nonsexual touching, and lots of attention to their every remark (Singer \& Lalich, 1995:114). During the recruiting the predisposition of new members is also addressed. Predisposition factors refer to aspects such as feeling "different" from others, or not really belonging somewhere. In the potential members' contact with the cult, they experience that these factors are addressed. They feel loved and understood and are listened to (Whitsett, 1992:363). The utilisation of these techniques creates the perception of affectionate interest in the well-being of the individual. This perception not only causes an emotional desire to return and make more contact, but also creates a seemingly safe environment which influences the critical facilities of the person. The first contact has the aim of stimulating an interest in the group and its activities. Once that interest is established, the next phase can take place.

\subsubsection{Loosening}

Loosening is the phase during which the leader starts to loosen the individual from his or her existing way of life. A successful way of achieving this is through inducing guilt. All the recruit's former personal connections are deemed evil by the cult and are shown to 
be against "God's chosen way" (Singer \& Lalich, 1995:118). It is also established by sowing seeds of doubt about the correctness of the individual's identification structures. For example, it is almost impossible for adolescents and young adults not to have mixed feelings about their parents, their church, politics, educational institutions and the world in general. Many cults make a point of tapping into these unresolved feelings, by exploiting and playing them down in order to attract and recruit members. Control is systematically gained over the prospective members by increasing anxieties and fears exploiting dependency needs and provoking feelings of guilt and inferiority (Meerlo, 1956:73). With the prospect that the cult has the answers to all life's questions, even to addressing unresolved feelings, the prospective member is subtly induced to get more involved in the cult practices.

\subsubsection{Change}

The new member's gradual commitment to the activities of the group creates the opportunity for change. In order to bring about real change in attitude and behaviour, certain techniques are introduced. Some of the most powerful techniques will be discussed.

- Change is brought about through confession sessions. Through public confession sessions new members are led to reveal past and present behaviour, contacts with others, and undesirable feelings, seemingly in order to unburden themselves and become free. The member is stripped of his or her private and intimate feelings. Whatever is revealed is subsequently used to further mould the member and to make him or her feel closer to the group and estranged from non-believers. The information can also be used against the member to make him or her feel more guilty, powerless, fearful and in need of the cult and the leader's goodness. A strong emotional tie is also formed between the member and the cult as a result of the self-revealing confession (Singer \& Lalich, 1995:72; MacHovec, 1989:82). Through the confession sessions and instruction in the group's teaching, members learn that everything about their former lives, including friends, family and non-members, is wrong and must be avoided. Outsiders will pull the member away from God and pollute him or her.

- Group pressure is another effective means to get people to fit their behaviour to group norms. Cult leaders use the innate tendencies toward group conformity that people bring with them as a powerful tool for change. No one announces the rules, but 
people look around them, discern what they are and behave accordingly. For example, a number of women in a cult, without being instructed to do so, changed their clothes to dark colours, long skirts, flat heels and no make-up in order to fit in (Singer \& Lalich, 1995:168). People tend to believe that the majority is always right. When confronted with information contradictory to the individual's own world-view, the reaction of the other established members is observed in order to assist in dealing with the information. The positive reaction by these established members causes new members to re-evaluate their own response. In most cases the new members believe that they must be wrong because all the other members accept the information. The pressure by the group subtly persuades the new member to accept the information.

- Sensory deprivation is also a powerful means to bring about change. Under extreme sensory deprivation people often show decreased intellectual functioning and mood shifts, and even visual and auditory hallucinations. Sensory deprivation can diminish an individual's ability to resist attitude and belief changes. Stress that is experienced during deprivation makes some individuals especially sensitive to social influence (Suedfeld, 1975:60-69). Singer and Lalich (1995:132) mention two important sensory deprivations common to cults, namely prolonged dietary changes and prolonged sleep loss. Members of the Alon Christian Fellowship are expected to participate in all activities. One such important activity is prayer meetings. Members living on the farm are expected to pray at 05:00 every morning. Those who miss these meetings are told to look for another place to stay because they are not committed and do not belong on the farm. On Friday nights they are expected to pray for the Jews. These prayer meetings can last up to midnight and even later. At three the next morning they are expected to start praying again. Those who have difficulty in doing that are accused of being lazy or not committed (Miller, 2003). Many cults institute vegetarianism as a requirement for their members. At Alon Christian Fellowship, members are mostly fed carbohydrates and a small amount of protein (Miller, 2003). Cult members are put on low-protein, improperly balanced diets with no concern for proper nutrition; this causes odd sensations in the lower digestive tract. A spiritual explanation for this is that it is "doing battle with Satan". The lower intestinal pains they experience are evidence of their sinfulness and their need to learn the group's ways of battling with Satan. 
In many cults the members are involved in exhausting work routines, often going for months on three to five hours of rest a night, with occasional total collapses into sleep, for which they are berated, because they were "lazy" or "sinful" (Singer \& Lalich, 1995:134). Some former cult members reported that as a result of deprivation they were unable to perform more or less routine tasks or to concentrate on anything other than their private religious experience (Pavlos, 1982:24).

Sensory deprivation and the obvious physical responses to it can be reinterpreted and reframed as desired by the group leader and presented as evidence of whatever the leader says (Singer \& Lalich, 1995:135).

- Information overload is also used. During regular sessions the cult members are bombarded with loads of information. A human being can only absorb a limited amount of information in an analytical way. When too much information is given, a person will simply absorb it uncritically. With gross overstimulation, the person may have a psychotic episode (LeBar, 1989:188). Together with this overload of information, two other techniques are also used. One such technique is purposeful confusion - the leader will, for example, make the following statement, well knowing that members are starting to get confused: "The more you try to understand what I am saying the less you will understand, do you understand?" What this actually means, is that the members should not listen critically to what they are told, but must trust and accept whatever the leader presents as the truth. Eugen Houy taught his followers to consult him for the clarification of any Biblical Scripture. He also discouraged critical evaluation by saying to them: "if you think you will sink" (Erasmus 2004:80). Another technique is known as two-sided persuasion a technique that subtly confirms the special calling of the leader in order to make members accept what he or she says and obey it. For example, the leader will tell the followers: "Those of you who doubt my calling - you should know that the doubt is sown by me and because of my knowledge of that doubt, you should know that I am really from God."

The ultimate goal of the change phase is to produce a new social identity. When the cult refers to the new identity they speak of a member who is converted, transformed or reborn. The new identity is demonstrated by coherence with the prescribed behaviour of the cult. Once the member is converted, he or she needs to be established in the cult lifestyle. 


\subsubsection{Establish in cult lifestyle}

During this phase the follower has already redefined his or her life as part of a new movement dedicated to God and has internalised this new life through the teachings and techniques of the group. The members are completely committed to the group and the leader. Members have sacrificed their finances, possessions, family and friends in order to be totally committed to the calling of God. All bridges have been burned, and with the realisation that no support networks exist outside the group, they are inwardly focused.

The followers are also kept in this new behaviour pattern by means of other subtle techniques such as fear, guilt, internal spying and punishment if someone does not act according to the rules of the group or leader (Singer \& Lalich, 1995:77). Punishment includes above all to be ignored or rejected by the other members, until the victim confesses. It also includes doing the dirty work in the group. Hennie van Niekerk of the Emmanuel Fellowship punishes his followers physically. One lady who was disobedient to God had to plant potatoes in a piece of land with her own hands. After the plants bore fruit, he ploughed them into the soil again with the words: "Don't think that you or anybody else will eat the fruit of your hands" (Van Niekerk, 2004a). Another male member of the same group was excommunicated when he asked to be excused from one Friday night's youth meeting because he was very tired. The leader reacted furiously, accusing him of being lazy and not committed and stating that he would never be allowed in any meeting again. This particular member went back to the leader after a while, begging him for forgiveness and a second chance (Van Niekerk, 2004b). On the other hand there are also rewards for those who are obedient, which mainly consist of praise given to the specific members by the leader.

It is evident that after undergoing the process of mind control, a cult member is caught up in a situation that is difficult to escape for the following reasons:

- The internalised belief that it is God's way and will for them and the commitment they have made already.

- Loyalty and the fact that people want to achieve something and do not easily renege on a commitment.

- Respect for the authority figures that give answers.

- Peer pressure. Nobody is allowed to speak out. All the others seem to be going on; if I want to leave the group something must be wrong with me. 
- Exhaustion and lack of information increase cult members' inability to act.

- Separation from the past.

- Fear of possible punishment, but also that they could not survive in the world outside the cult.

- They feel guilty about turning their backs on the group, especially after they have actively participated.

\section{After-effects for cult members}

Leaving the cult is extremely difficult for many former members, especially if they have to do it alone. The hold on members obtained through the sophisticated techniques mentioned above has lasting effects on members who leave a cult. Having left the cult, they have to face the challenge of re-entering the society they once rejected. According to MacHovec (1989:80-81) and Singer and Lalich (1995:301), the following general after-effects are experienced by former cult members:

- depression and sense of alienation;

- loneliness;

- low self-esteem and low self-confidence;

- phobic-like constriction of social contacts;

- fear of joining groups or making commitments;

- distrust of professional services;

- doubt of own ability to make good choices;

- problems in reactivating a value system to live by.

Singer and Lalich (1995:301) identified the following areas in which such people need assistance. The former cult member needs adjustment in five major areas: practical living, psychologicalemotional, cognitive, social-personal and philosophical-attitudinal.

\section{Summary and conclusion}

Why is it important to know about cults and their activities? No one joins a cult of their own free will. Cults take away people's freedom through the application of unethical techniques. Cults take away people's possessions. Cult leaders have succeeded in getting wealthy and not so wealthy people to turn over amazingly large amounts of money and even more possessions. Cults escape 
scrutiny because they hide behind the country's constitution. This not only frees them from paying taxes, but also provides cults with certain privileges they surely have never earned.

The right to be part of the religion of your choice should also be protected when cults subtly, under the guise of religion, intrude on that freedom. By the utilisation of sophisticated techniques, people's good intentions of committing their lives to the service of God lead to their becoming slaves to the aims of a cult. Cults function quite unhindered and with great ease, mainly because the techniques utilised by them are not visible to the untrained eye. In most cases the outward appearance of cults even creates the impression of utopia. If leaders are confronted about their practices, the common answer is that the followers are of age and are there out of their own free will. This loophole in the freedom of religion should be brought to the attention of the government. Precautionary measures must be put in place from government level in order to guard against religion becoming a platform for human rights abuses. Church leaders should also educate their congregations in this regard.

A greater awareness in general on all levels, accompanied by action will ensure that these groups are exposed for who they really are. The chances of damage to innocent people will be minimised and the victims that fell prey to these groups will be supported with greater understanding, in order to restore worth and belonging in their lives.

\section{List of references}

BOTHA, P.R. 1993. Mind control and the Bloomberg cult. Pretoria: Ongepubliseer.

BOWKER, J. 1997. The Oxford dictionary of world religions. New York: Oxford University Press.

ERASMUS, J.J.J. 2004. Die Houy groep: Kerk of kulte? Potchefstroom: PU vir CHO. (Th.M.-skripsie.)

FACTNet, s.a. Mind control: Definition and information. http://www.factnet. org/mindcont.htm?FACTNet [18 Febuary 2005].

FESTINGER, L. 1957. A theory of cognitive dissonance. Stanford: Stanford University Press.

GERARD, H.B. 1992. Dissonace theory: Acognitive psychology with an engine. Psychological Inquiry, 3(4):323-327.

GOUWS, L.A, LOUW, D.A., MEYER, W.F. \& PLUG, C. 1982. Psigologiewoordeboek. Johannesburg: McGraw Hill.

HASSAN, S. 1988. Combatting cult mind control. Rochester: Park Street.

HEXHAM, I. 1993: Concise dictionary of religion. Illinois: InterVarsity.

HUNT, S.J. 2003. Alternative religions: A sociological introduction. Hampshire: Ashgate. 
LEBAR, J.J. 1989. Cults, sects and the New Age. Huntington: Our Sunday Visitor.

MACHOVEC, F.J. 1989. Cults and personality. Illinois: Thomas.

MCMANUS, U. \& COOPER, J.C. 1984. Dealing with destructive cults. Grand Rapids: Zondervan.

MATHER, G.A. \& NICHOLS, L.A. 1993. A dictionary of cults, sects, religions and the occult. Grand Rapids: Zondervan.

MEERLO, J.A.M. 1956. The rape of the mind: The psychology of thought control, menticide, and brainwashing. New York: World Publishing.

MILLER, K. 2003. Persoonlike medeling - ex-lid, 17 April.

PAVLOS, A.J. 1982. The cult experience. London: Greenwood.

SINGER, M.T. \& LALICH, J. 1995. Cults in our midst. San Francisco: JosseyBass.

SNOW, D.A. \& MACHALEK, R. 1984. The sociology of conversion. Annual Review of Sociology, 10:167-90.

SUEDFELD, P. 1975. The benefits of boredom: Sensory deprivation reconsidered. American Scientist, 63:60-69.

THERON, J.P.J. 1993. When a "word of prophecy" becomes the "word of God". Missionalia, 21(3):287-310.

VAN NIEKERK, A. 2004(a). Mededeling aan Special Assignment, SABC3, 11 Mei.

VAN NIEKERK, J.P. 2004(b). Persoonlike mededeling, ex-volgeling, Emmaneul Fellowship. 11 Mei.

VENTER, M.A. 2002. Instandhouding en regulering van die selfkonsep tydens psigiese beheer "mind control". Tydskrif vir Christelike Wetenskap, 40(1 \& 2):135-153.

WHITSETT, D.P. 1992. A self psychological approach to the cult phenomenon. Clinical Social Work Journal, 20(4)363-375.

\section{Key concepts:}

behavioural change

cults

mind control

religious cults

\section{Kernbegrippe:}

gedragsverandering

godsdienstige kultes

kultes

mind control 
Mind control: The secret weapon utilised by religious cults ... 